\title{
Real Estate Business Development Strategy In Approach to Business Model Canvas (Case Study at PT Mekar Agung Sejahtera)
}

\author{
Prihardini Mufti $^{1}$, Rizal Syarif ${ }^{2}$, Setiadi Djohar ${ }^{3}$ \\ ${ }^{1}$ Magister Management and Business Bogor Agricultural University, Gedung SB IPB Jl. Raya Pajajaran Bogor, Indonesia 16151
}

\begin{abstract}
The Business Model Canvas (BMC) helps the companies in creating their business models based on nine building blocks. BMC is a tool that provides a clear view of what the company needs to achieve and focuses on the strategies elements that matter most and will have the greatest impact to the business. Along with the government program to realize the program of "Satu Juta Rumah" and the need for an unfulfilled housing backlog, PT Mekar Agung Sejahtera as a research model is one of the real estate developer running its business with its own strategy. The method used in this research was descriptive analysis with Business Model Canvas, Epicenter and External Environment. The identification result on this research is align each element in the company based on BMC and managerial implementation to recommendation that The need to create Value proposition by further developing the business model of the canvas made the company experiencing the organizational structure of the addition of Research and Business Development division.
\end{abstract}

Keywords: Business Model Canvas, Epicenter, External Environment, Real Esatate

\section{Introduction}

An increasing number of population which is accompanied by an increase number of needs, especially the primary needs of the availability and affordability of shelter become one of the factors that lack of housing needs. The housing sector is an important and strategic sector for the economy, this is because the provision of a house becomes an important part in the advancement of a country. On the other hand, the housing sector is the key of the economy because it is one of the driving factors of other industries.

With the growing and increasing competition of the real estate industry causing the movement of cumulative housing developers, although there are still developers who are not active. This encourages housing developers to be more observant in formulating marketing strategies and has a strong business orientation so that marketing performance and differentiation of housing products become more attractive compared to other housing developers. From the data reported by the Biro Riset Kontan to the average revenue of listed companies per sector indicates that the property and real estate industry in 2013-2014 experienced a very sharp decline, which amounted to $87.36 \%$ compared to 2012. The decline in revenue is due to the impact of the global economic crisis that impacts on the inability of the market or the public in buying property and real estate.

The issue of housing availability and affordability becomes an issue that will never be finished. This is because the percentage level of housing needs is always increasing in each year. According to data released by BPS, the difference between the availability of housing and the increasing number of housing demands has gaps. In 2013, the total number of houses to be fulfilled reaches 14,000 units. Meanwhile, according to the World Bank, the number of home growth reaches 250,000-400,000 units per year. Empirical data from the State Ministry of Public Housing also shows that the provision of formal housing provides only $15 \%$ of the national housing needs in cooperation with the government, the remaining $85 \%$ of these shortages are selfsufficient from private housing developers and secondary market. The system of housing development by the government and private developers is the housing procurement scheme offered through the formal market mechanism with credit facilities (KPR) for the buyers.

PT Mekar Agung Sejahtera, which is subsidiary of MAS GROUP, to maintain its existence in facing the changing business environment and competitor of subsidized housing is by emphasizing the importance of strategic role of a company management and integrity system. The success of a company in competing is strongly supported by the ability to anticipate changes that occur in the internal and external environment of the company, as well as the ability to react faster than competitors.

According to Giesen et al (2007), the company's best way of dealing with large-scale changes in various construction and property industries is to focus on business model innovation as a way to win competitiveness and growth. Business model innovation is critical to achieving success in the present and the future in rapidly changing and increasingly complex environmental conditions, so that the company leaders need to understand when to adapt to the business model and how to implement its change. So in this research will develop the strategy development by using business model innovation and analyze all factors namely macroeconomic factors, key trends, market power analysis and industry analysis.

Wheelen and Hunger (2010) state that business model is a method used by companies to generate money and value in the business environment in which the company operates. The concept of a business model can reflect a strategy made from a point to the next. Business model analysis is also able to expand and deepen organizational knowledge to know

\section{Volume 6 Issue 12, December 2017}




\section{International Journal of Science and Research (IJSR) \\ ISSN (Online): 2319-7064}

Index Copernicus Value (2016): 79.57 | Impact Factor (2015): 6.391

about the basic components of a business model. The company tries to have the ability to produce a proportion of value that can not be fulfilled by its competitors so it must have a quality component so that what the company expects to achieve. According Slávik (2014) the most complex model of business concept is the business model canvas (BMC) from Osterwelder and Pigneur. This business model illustrates not only economic and business processes but how to create company value. Another advantage of the business concept of the canvas model is the scheme and has a universal visualization and explains the relationship process of the nine blocks.

\section{Previous Studies}

Destiani (2014) analyzed the canvas business model in his thesis entitled Analysis of canvas business model strategy at PT. Angkasa pura II untuk Bandara Internasional Soekarno Hatta. This study uses a business model canvas with SWOT and AHP analysis. The results of the improvement analysis Business Model Canvas for the development of the airport in the future by formulating strategies on 3 elements consist of key activities, key resources, and channels. Piority strategy on key activities elements is the expansion and development of activity on aeroneotics and non-aeronautics. The priority of channel element strategy is done by creating a complete and updated airport website periodically. The similarity of this study with Destiani (2014) is the use of the Business Model Canvas, SWOT and AHP analysis tools in determining alternative and strategic priorities.

Wisnu Sakti Dewobroto (2013) conducted a research entitled "The Use of Business Model Canvas As A Foundation To Create Alternative Business Strategy and Business Feasibility". The approach used is the business model canvas in approach with the projection of financial analysis. The results of this study show that the business of car sales 21 (Two One) can be categorized as feasible and can be run.

Gertrud Samuel (2012) conducted a research entitled "Business Model Innovation: an empirically served framework for early stage business model innovation". The methods used are business model canvas, SWOT, Buyer utility Map, GAP analysis. With the result that the company is engaging in the field of ball bearings, realizing that the product and market differentiation, the company needs to do the activation system and referring to the competitors. Research focuses on the process of business model innovation and generates frame work from each part of the business model.

\section{Method}

Research conducted at PT. MAS located in Grha Adhiyasa, Tangerang City, in June-August 2017. The selection of research sites conducted intentionally (purposive) with the consideration that PT. MAS is a company engaged in the field of real estate developers and follow the development of the program "Satu Juta Rumah Indonesia". This study uses descriptive method in the form of case studies on business development, by collecting data and information from various sources to answer the existing problems. Data obtained from the research are analyzed through several tools which are divided in this research stage as follows;

1) Descriptive analysis method, that is collecting data about current condition information of PT. MAS from internal and external companies from the process of discussion of opinion as a whole.

2) The company's business model analysis, which describes the business condition of the model used by the company currently using a business model canvas approach, this business model reviews the company from 9 elements (building blocks) namely: cutomer segment, value proposition, channel, costomer relationship, revenue stream, key resources, key activities, key partnerships, and cost structures. The elements exposure is based on actual business conditions, information data obtained from interviews with management, and completed with direct observation in the field.

3) Analyzing Environmental Aspects of the Macroeconomic Aspect, Industrial Strength, Key Trend, Market Strength.

4) Developing a Business Model Design with idea building with Epicenter, each core center acts as a starting point for major business model changes, and can have a powerful impact on all eight other building blocks. Occasionally, business model innovations arise from several centers.

5) Improved the design of a new business model created using an epicenter that spawned some creative ideas that allowed for the development of the company, and implemented the business model in accordance with PT MAS.

\section{Result}

\subsection{Identification of Elements of Business Model Canvas}

The Focus Group Discussion (FGD) method is used to identify, analyze and improve the business model canvas development by PT Mekar Agung Sejahtera (PT.MAS), identification effort includes descriptive and analysis of nine elements of building box with workshop. Prior to the identification, the speakers were equipped with an understanding of concept, methodology and work width to describe and analyze the business model canvas. In this research, the analysis conducted at PT. Mekar Agung Sejahtera in the project of low-cost housing succeeded the government program "Satu Juta Rumah Indonesia" which is Grand Sutera Lewiliang (GSL) located in Bogor area can now be identified as follows:

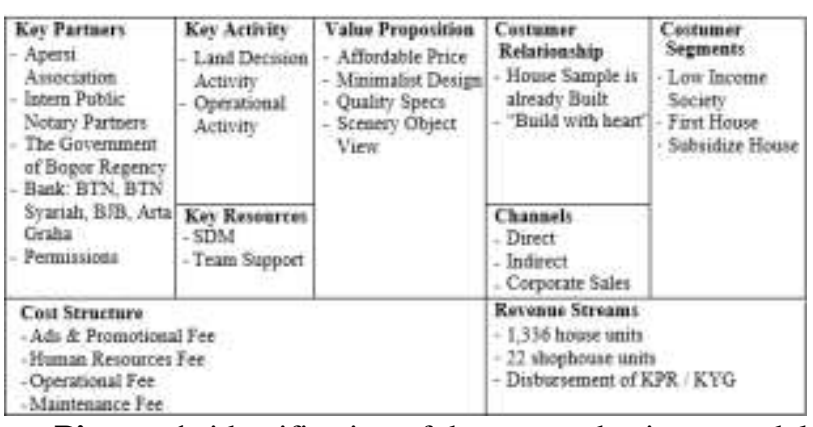

Picture 1: identification of the current business model canvas 


\section{International Journal of Science and Research (IJSR) \\ ISSN (Online): 2319-7064}

Index Copernicus Value (2016): 79.57 | Impact Factor (2015): 6.391

\subsection{Epicenter}

Business Model Canvas PT. Mekar Agung Sejahtera that has been identified and analyzed further improvement. There are several improvements that need to be done by the implementation of the future business model canvas. Development of business model of canvas for subsidized housing succeeds government program through funding FLPP (Fasilitas Likuiditas Pembiayaan Perumahan) conducted by research study on development project at Grand Sutera Lewiliang, by using the refinement priority refers to the center of innovation (Epicenter) that is racing on the center of the Key Resources segment can change and affect the eight elements of other canvas business segment segments: Key Activity, Key Partener, Cost Structure, Value Proposition, Costumer Segments, Channel, Costumer Relationship, and Revenue Stream.

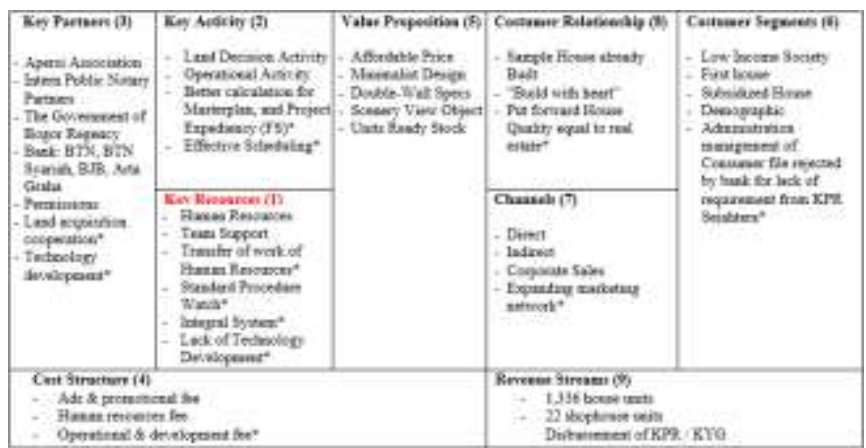

Picture 2: Identify the business model canvas using epicenter

\subsection{External Environmental Analysis}

"Innovative Design Space" creates a better business model by mapping the Nine main elements in the Business Model Canvas and analyzing in a business model environment contest that is classified into four major element areas.

\subsubsection{Market Power}

\section{Strategic Issues on 2017}

The property market is heavily influenced by the stimulus factors that the government continues to issue directly or indirectly to the property sector that will strengthen national economic growth. Some of the stimuli that have the potential to provide additional power for the property and property market to continue to grow include:

\section{Interest rate}

Industry Property Watch estimates that the BI Rate of 7- day Reverse Repo Rate will still be maintained at $4.75 \%$ at least until Q1/2017. This is taken by Bank Indonesia to maintain domestic macroeconomic stability amid global financial market uncertainty. Furthermore, BI will continue to strengthen coordination with the government with a focus on controlling inflation to stay within the target range and structural reforms to support sustainable economic growth.

\section{LTV and Inden Loosen}

The loosening of Loan To Value (LTV) rules, including returns on a pivot that have been issued by BI soon will have an adverse down to $15 \%$ from $20 \%$ and the opening of a ban on home purchases on a pivot basis for the second mortgage. Nevertheless, Indonesia Property Watch considers that the down payment should be lowered to provide more impact on the market. In the future there will be a new regulation that will be expected to have a significant impact on the national housing and property market.

\section{Infrastructure development}

The current largest infrastructure development in Indonesia's history is estimated to have tremendous impact on the national economy. The movement of goods and services will be more effective and efficient so that trade flows can be further improved. In the end, purchasing power will rise and the housing and property market will surely enjoy the results. Infrastructure Plans including highways, mass rapid transit (MRT), Light rail transit (LRT), Railways to the development of "Kawasan Ekonomi Khusus" (KEK) will have a tremendous impact on the upgrading of the property market in the future.

\section{Program Sejuta Rumah}

Pro-public housing procurement program has since 2015 been issued by the government to increase the interest of developers to build low-cost housing with 5\% FLPP interest rate, $1 \%$ down payment and Rp.4,000,000 per unit advance assistance. While there is still much to improve, this program has led many developers to build low-cost housing that is badly needed by low-income people, let alone the government has raised the housing budget in 2017, although it is still very limited.

\section{Dana Investasi Real Estate (DIRE)}

Dana Investasi Real Estate (DIRE) is approximately not much different from the Real Estate Investment Trusts (REITs) that exist in other countries. DIRE tax cuts into single tax with a total tax of $1.5 \%$ should be an alternative financing of property projects. The amount of this tax is still $50 \%$ cheaper than REITs in Singapore which impose a tax of $3 \%$, Although in Indonesia has not been too popular but in the long run this instrument will be the choice of local developers.

\section{Final Income Tax}

Government Regulation Number 34 of 2016 Concerning the New Rate of Final Income Tax on Land Transfer of PPh from $5 \%$ to $2.5 \%$ for non-subsidies and $1 \%$ for subsidies will provide a passion for housing development not only low-cost housing but for the middle -cost housing to high-cost housing to expand the development. With the running of property projects then there are hundreds of related industries that will participate to grow that will turn the wheels of the national economy.

\subsubsection{Industrial Strength}

\section{The market shifts to the lower middle segment}

The market continues to shift to the middle to lower segment. Based on the price segmentation of the home ual can be shown that the market with price segment below Rp.300.000.000,- contributed $34.9 \%$ followed by lower middle segment (Rp.300.000.000,- - Rp.500.000.000,-) of $33.8 \%$, then the middle segment (Rp.500.000.000,- -

\section{Volume 6 Issue 12, December 2017}




\section{International Journal of Science and Research (IJSR) \\ ISSN (Online): 2319-7064}

Index Copernicus Value (2016): 79.57 | Impact Factor (2015): 6.391

Rp.1.000.000.000,-) is $23.8 \%$, and the upper middle segment (> Rp.1.000.000.000,-) is 7.5\%.

\section{Form of consumer financing}

With the condition of interest rate trends declining impact on the form of consumer financing lower middle segment began to shift to the form of credit respectively. Based on the analysis conducted with segmentation of building area, $85.2 \%$ of consumers who bought some small type of house with building area until T.36 choose to use KPR / KPA. Not different for the purchase of houses in the middle class (T.36 - T.70) chose to use KPR / KPA of $82.2 \%$. In the upper segment (T.> 70) though most $75.4 \%$ are still using KPR / KPA, but a hard cash purchase of $12 \%$ or $12.6 \%$ gradually also shows considerable contribution.

\section{The market proceeds slowly until mid-year}

The actual property market has shown an increase in Q3 of 2016, still hampered its movement until the end of 2016. In early 2017, the market was not scattered. The impact of several factors outside the cycle, suspected to be due to the movement of the property market is higher. Political and security factors are still a bit in the spotlight for investors to want to buy property.

Looking back from the previous cycle, the property market began to rise in 2009 to 2013 , within 4 years for the property market to its peak. Property prices rose uncontrollably. On the one hand, this hike buoys investors, but on the other hand, this increase makes the property market vulnerable because the increase is too high and indicated over value. Although there will be no big property bubble increases, but with this condition a property becomes longer in the market to sell again.

But in this condition does not mean the market condition of loss of purchasing power, the market is just waiting and playing in the property market with prices still relatively still reasonable, given the current upper middle market is considered already overpriced. This is in line with the prediction that the main market is the property market in the middle price range in the price range Rp.500.000.000 to Rp.1.000.000.000, - in general.

The market will show a very real movement when seen from the positive impact that will decline until the second quarter of 2017. Tax amnesty program that has ended at March 2017 with the achievement that the repatriation will continues to enter. Some infrastructure projects have begun to be felt. With the national economic trend improving, then at least in the second half of 2017 it seems the market will look more real (although the big cycle has been seen in Q3 / 2016.

But there is a slightly different from the current market cycle. With an estimated second half of 2017 the market will rise, then the time to reach the peak of 2019 when the estimated period of the cycle, becomes shorter or less 1.5 years. We hope that the national property market will continue to contribute positively to the nation and the country, not just the upper middle segment, but the simple housing market is growing.

\subsubsection{Key Trends Program Satu Juta Rumah}

The "Satu Juta Rumah" program is doubtful of its success, looking back on how the targeted housing target in Indonesia, the highest attainment of subsidized KPR subsidies has never been achieved. The highest achievement of average subsidized KPR distributors until 2016 was 111,627 units per year. Figures achievement of this program will be even further if you see that most of the supply of simple homes done by private and not government.

In addition to the demand-related aspect of purchasing power, the government has undertaken various incentives to increase purchasing power as it does with a million home program. In terms of financing also made some breakthroughs although still need to be supported with the government budget and long-term funds that can support this program in the future. However, the crucial factor is the supply side where the government must guarantee the availability of land for houses in the Million Houses Program, if the price of land for public housing can not be controlled by the government, it will be difficult for the private and the private sector to succeed in this program.

The program policies related to FLPP interest rate of 5\%, the amount of $1 \%$ down payment, and Rp.4.000.000 advance payment, will be helpful. But that alone is not enough because only pay attention to the demand side that can make consumer purchasing power go up. However, in order to avoid the existing market mismatch, the concept of the supply side should be more mature, besides these factors affecting the supply side are closely related to licensing issues. Starting from the cost to the old process, not to mention the spatial problem in each region that has not provided clarity limits specifically for cheap houses so that the government can not guarantee the availability of land.

Based on the analysis undertaken, at least this "Program Satu Juta Rumah" will last only in the next 3 years. Not without reason, the inventory of land owned by small developers who build houses with FLPP facilities is increasingly limited, meaning that after the ground runs out the small developers have difficulty to get land suitable for low-cost housing because the price is too high. This illustrates the fundamentals of the national housing market is still very weak.

Economic growth in Bogor district is high at $6.06 \%$ based on data from the Central Bureau of Statistics last year 2014, tourism sector also shows the increase of tourist visits to tourist attraction in Bogor regency, both domestic and foreign tourists, as many as 5.014.475 tourists or grow $119.39 \%$. This growth is expected to continue to increase with local government efforts to diversify tourism products and increase tourist destinations.

\subsubsection{The strength of the macro economy Potential Infrastructure}

Bogor certainly has great potential with the Bogor Outer Ring Road (BORR) road network and Bogor Inner Ring Road (BIRR). From the plan of the three sections of BORR development stage. Some of the land crossed by BORR will

\section{Volume 6 Issue 12, December 2017}




\section{International Journal of Science and Research (IJSR) \\ ISSN (Online): 2319-7064}

Index Copernicus Value (2016): 79.57 | Impact Factor (2015): 6.391

certainly increase soon. Currently, the area of North Bogor has been growing first and continues to lead to Bukit Cimanggu City, Taman Yasmin and Dramaga.

Bogor Regency Government will also build a Central-East Poros road that will connect Cibinong to Bekasi (Delta mas) and Cianjur. The Central-East Poros Road is excluded from the Sentul circuit. Not to mention the planned BoCiMi Toll Road (Bogor-Ciawi-Sukabumi) that will cross the Rancamaya corridor which is sure to be the main alternative to crossing from Bogor-Sukabumi. Toll Bocimi is ensured as an alternated congestion parser that often occurs in this path. In addition to toll roads, the planned development of alternative roads at the Cibinong Sports Arena (GOR) from Tegar Beriman Road across Tajurangal to Parung will open up tremendous access to the surrounding area. The latest plan is the development of Light Rail Transit (LRT) which will connect Jakarta from Cawang to Bogor. As far as the LRT station in Bogor, we are still focusing on the first stage development until Cibubur.

\section{Direction of Regional Development}

The direction of the development of Bogor area is located in Bogor Regency with the capital of Cibinong. These developments have resulted in the widening of regional development in South Tangerang, Depok and Jakarta. Characteristics of the development of this region in addition to toll access, the rail network was still the main choice, especially from the south direction of Depok and Cibinong. Some development points such as Sentul, Dramaga, Tajur Halang, Parung, and jonggol are expected to increase. Some development points such as Sentul, Dramaga, Tajur Halang, Parung, and jonggol are expected to increase. In addition, the LRT trajectory is expected to strengthen this area as a new buffer center of Jakarta.

\section{Property Development Opportunities}

Over the past few years the growth of hospitality business and the like continues to grow and develop in the city of Bogor to Cisarua. The market of apartments that grow and grow in large as supporting the accommodation and tourism sector is not yet as a dwelling. In the housing sub-sector, the market pull from Jakarta for the middle to lower segment is still concentrated in areas with rail access

\subsection{The Improvement of Business Model Canvas}

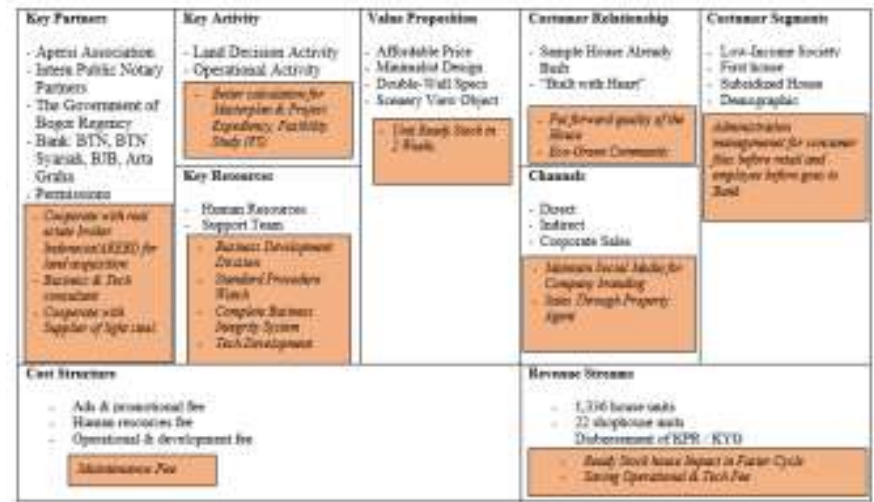

Gambar 7: Identifcation of the Improvement of Business Model Canvas

\subsection{Managerial implications}

Creating a new value proposition with key partner development technology development, improve the management system to be more directed so that it will be easier in synchronizing every existing elements in the company and the Canvas Business Model development will make the company experience an organization structure change by adding $\mathrm{RnD}$ division, hand in hand with the land acquisition with AREBI.

\section{Conclusion \& Suggestion}

The result of the analysis done with Canvas Business Model can be used to analys real estate developing strategy by knowing the more integrated management system and can synchronize every elements in the company.

The result of the recommendation of managerial implementation that need to ceate a value proporsition with developing the Canvas Business Model more will make the company experience the additional organization structure that is $\mathrm{RnD}$ division.

Monitoring and evaluation is need to be done periodically so that the company can apply the new strategy well, hand in hand with land acquisition with the AREBI association and trading with property agent.

We advice all the reades to analise this result more for the development of real estate and property business.

\section{References}

[1] D. Destiani, “Analisis Strategy Model Bisnis Canvas pada PT. Angkasa Pura II untuk Bandara Internasional Soekarta Hatta". Institut Pertanian Bogor, Indonesia, 2014.

[2] J. Geterud, T Samuel,'Business Model Innovation: an Empirically Derived Framework for Early Stage Business Innovation", Goteborg (SWD), Chalmers University of Technology, Departement of Technology Management and Economic, 2012

[3] E. Giensen, S. Berman, R. Blitz, A, Path to Success Three Ways to Innovate Your Business Model. IBM Global Business Service, Vol. 35 No.6 2007 pp 27-33.

[4] Team PPM Management, "Canvas Model BusinessPenerapan di Indonesia", Pendidikan dan Pelatihan Management, Jakarta, Indonesia. 2012

[5] A. Osterwelder dan Y. Pigneur, "Business Model Generation", PT Elex Media Komputindo, Jakarta, 2012.

[6] A. Osterwalder, "The Business Model Ontology a Proposition a Design Science Approach", Universite De Lausanne Ecole Des Hautes Estudes Commerciales, Zurich, 2004.

[7] C. Zook and J Allah, "The Repeatable Business Model: Leveraging a Simple Formula Allows Corporation to Create New and More-lasting Differentiation," Journal Harvard Business Review, Boston 14(2) : pp 1-9, 2011.

Volume 6 Issue 12, December 2017 


\section{Author Profile}

Prihardini Mufti received the Bachelor degree in Agriculture from Bogor Agricultural University (IPB) in 2014 and Magister degree in Management Business from Executive School of Management Business Bogor Agricultural University in 2015 until now. During 2014, she works on Dini Karya General Building Contractor.

Volume 6 Issue 12, December 2017

www.ijsr.net 